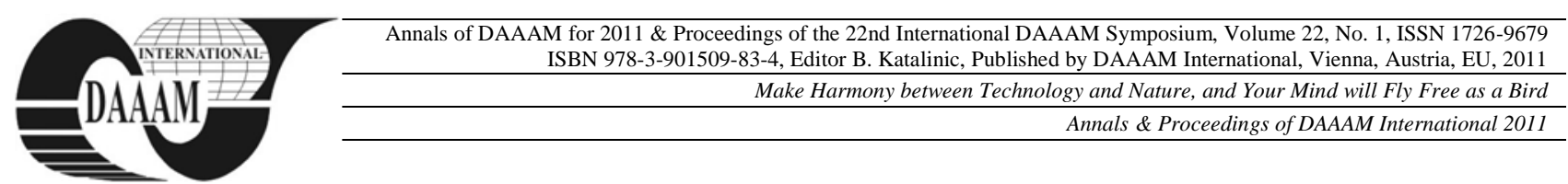

\title{
COMPARATIVE STUDY ON CONSTRUCTION PUBLIC INVESTMENT REGULATIONS IN ROMANIA AND GERMANY
}

\author{
NEGRUT, M[ircea] L[iviu] \& MIHARTESCU, A[na] - A[ndreea]
}

\begin{abstract}
The paper objective is a compared study of regulations and procedures with regard to award of public investments in the construction sector, in Romania and Germany. By analyzing the existing regulations in the two countries, we will seek solutions for a more efficient use of financial resources from the budget, with increasing quality and reducing the duration of projects execution works and disputes between the contracting and construction companies in Romania. Conclusions can be a point of view, to improve contractual conditions and working environment in construction, among participants in public/private sector investments in Romania.
\end{abstract}

Key words: construction works, public award procedures, standardized contract conditions

\section{INTRODUCTION}

From the examples seen in Romania, we notice that construction works often takes much longer and cost more than was planned. These happen for various reasons, contractual disputes between the parties and, vagueness or lack of contract conditions, are among the main reasons.

The paper highlights a fundamental research that consists in analysis, processing and assimilation of base knowledge, found in international usage, to make changes in the procedures of awarding, contracting and management of public construction works.

\section{RESEARCH METHODOLOGY}

The research method used in the scientific paper is the observation, which consists in analyzing the legislative framework in Romania and Germany on the implementation of public contracts award. The research methodology is presented in Figure 1.

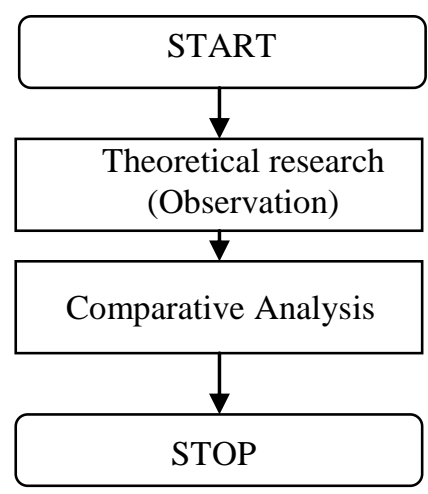

Fig. 1. The research methodology

Comparative analysis will highlight similarities and differences in the legal framework for contracting public works construction in the two EU countries. Based on this comparative analysis will outline the conclusions of the paper.

\section{COMPARATIVE ANALYSIS OF AWARDING AND CONTRACTING PROCEDURES IN CONSTRUCTION}

At present, the European construction industry is characterized by increasing internationalization and a reduction of entrance barriers to local markets. Therefore, there is a strongly growing demand by companies and organizations active in the construction sector for information on foreign construction markets and information necessary for international cooperation.

In Romania the contracts forms are generally based on commercial contracts requirements, but in construction industry are need certain regulations and there are several different types of contracts.

\subsection{Awarding and contracting procedures of construction public works in Romania}

In the context that Romania has become a member of the European Union, the legal framework on public procurement has underwent substantial changes, aimed to bring it up to the EU standards, mainly by implementation of the relevant directives into the Romanian legislation (Global Legal Group, 2010). Currently the Government Emergency Ordinance No.34/2006 on the awarding of public procurement contracts, concession contracts for the public works and contracts for the concession of services, sets out the general legal framework of public procurement in Romania.

GEO No. 34/2006 transposes the rules and principles established by the EU law provided under Directive 2004/18/EC, Directive 2004/17/EC of the European Parliament and of the Council of March 31, 2004, and of Council Directive 92/13/EEC of February 25, 1992.

GEO No. 34/2006 explicitly provides that the fundamental principles at the base of any award of public procurement contracts are: non-discrimination; equal treatment, mutual recognition, transparency, proportionality, efficiency in using public funds, and assuming of responsibility (Global Legal Group, 2010).

GEO No. 34/2006 covers the following three main types of contracts:

(1) Public procurement (acquisition) contracts (including the fields of water, energy, transportation and postal services);

(2) Contracts regarding the concession of services by a contracting authority to a private entity; and

(3) Contracts regarding the concession of public works by a contracting authority to a private entity.

Over the time GEO No. 34/2006 was amended with various other laws.

The contracting authority has the obligation to state accurately within the tender documentation any request, rule, criteria and other necessary information, in order to ensure that the bidder is completely, justly and explicitly informed regarding the way of conducting the awarding procedure (Global Legal Group, 2010). 
It is compulsory for the terms of references, to contain the technical specifications, prescriptions, technical characteristics needed to describe, in an objective manner, in order to meet the requirements of the contracting authority.

The criteria for awarding the public procurement contract can be:

- The most profitable bid from the economic point of view;

- Exclusively, the lowest price.

Unfortunately, GEO No. 34/2006 is a general law which regulates the procedures for awarding public procurement contract, the concession of public works and services concession contract, but does not cover the main recommendation of some contractual conditions.

Contractual conditions can protect contact performance in the conditions earned by auction, or may allow substantial changes to the initial conditions, especially by the lack of their inclusion. These changes can have significant influence on the main objectives of construction projects, such as value, quality and duration of the project.

\subsection{Awarding and contracting procedures of construction public works in Germany}

The basic principles of German public procurement law are the same, which are underlying the EC public procurement Directives. For the performance of construction works, the relation between client and contractor is governed by a construction contract.

The essential components of this construction contract are:

- the provisions under public law, e. g. the German Civil Code, the Federal Building Act, and the Building Regulations of the Länder

- the German construction contract procedures, VOB (Verdingungsordnung für Bauleistungen)

- the conditions concerning contracts for supplies and services, VOL (Verdingungsordnung für Leistungen)

- the relevant technical codes, e. g. the DIN Standards

- the general and supplementary contract conditions of client.

The specification with bill of quantities, embedded in this framework, is the most important part of the construction contract. Beyond that, the VOB plays a central role in the execution of the construction work.

Under German procurement law, technical specifications serve the purpose to describe the work, supply or service to be performed under the contract, which is being awarded. All descriptions have to be "complete" and "exhaustive" in order to ensure, that each competitor bidding for the contract has the same understanding of the description of performance (Global Legal Group, 2010).

Contract award for public sector works is governed by the German construction contract procedures, VOB, which consists of three parts:

(1) VOB Part A: General provisions for the award of construction contracts;

(2) The standardized contract conditions, [VOB Part B: General contractual conditions for to the execution of construction work; and

(3) VOB Part C: General technical conditions of contract for construction work].

Tender actions pass through the following stages before completion of the construction work:

(1) Tender Specification: the designer prepares a specification containing work descriptions and quantities.

(2) Tendered Specification (priced): the price specification must be submitted by the tenderer to a certain date.

(3) List of Contract Works: the future contractor is selected and entrusted with the execution of the works.

(4) Accounting: interim valuations of the construction works progress are made, in accordance with the VOB and works are settled.
In accordance with the requirements of the $\mathrm{EC}$ public procurement Directives, contracts must be awarded on basis of the award criteria. The awarding authorities can choose between awarding the contract on the basis of the most economically advantageous offer or on the basis of the lowest price only. The criteria used have to be objectively, it is common to use a mixture of price and quality criteria to determine the most economically advantageous offer.

\section{CONCLUSIONS}

As shown above, I conclude that the legislative framework for public award procedures of construction contracts in the two countries analyzed, meet the Directives of the European Parliament and are quite similar. The differences can be observed in drawing up the specifications and technical specifications used to describe the construction works and prepare tender. They correspond to national procedures for specifications and tenders preparing. These differences are significant and have negative influence for the ongoing contract of Romanian contracting authority, because these are often technologically outdated.

In Romania does not exist regulation for General conditions of contract relating the executions of construction work, as there is in Germany, VOB Part B. The general technical conditions for quality control of works, as there are in Germany, VOB Part C, are also often technologically outdated.

In Romania, the absence of such regulations leads to numerous changes and contractual disputes between the parties. Unfortunately, these changes allow radical change of the initial conditions, obtained by public auction, which can lead to a substantial increase in value, extend the deadline for completion or lower quality. This is the reason, for which is necessary for construction works, to create certain national General conditions of contracting, that does not allow changing the main terms that were derived from winning the auction.

The result obtained in the paper can be used to start a research by government agencies at national level to define a set of conditions of the contracting. These should not allow changing quantities of work, unit prices, the deadline for completion, or the quality of work, only in exceptional circumstances.

By specifying clearly the responsibilities of each party and the conditions for achieving the construction works, it can increase efficient use, of public funds by reducing the number of disputes, and compliance with contract terms.

\section{REFERENCES}

Global Legal Group, (2010), The International Comparative Legal Guide to: Public Procurement, pp.105-110, pp. 200207 Publisher, Editor Global Legal Group, London

Zimmermann, J. (2010), Project Management. -Written lecture at the Department of Construction Process and Real Estate Development at the Technical University of Munich, Edition 06/2010, Munich

***, (2009), "VOB-B Procurement and construction contract procedures - Part B: General contractual conditions for the execution of construction works", DIN 1961:2010-04, DIN German Institute for Standardization, Berlin

***, (2010), „Emergency Ordinance no. 34/2006 on public procurement contracts, the public works concession contracts and services concession contracts", Version updated on 02/07/2010, ISSN 1453-4495, Official Gazette, no. 418 of May 15, 2006, Bucuresti

***, (2010), ,Emergency Ordinance no. 76/2006 amending and supplementing Government Emergency Ordinance no. 34/2006“, ISSN 1453-4495, Official Gazette no. 453 of July 2nd, 2010, Bucuresti 